\title{
Continued Clear and Practical Reform Policies Will Create a Positive Environment for French Companies in China
}

\author{
Christophe Lauras
}

\begin{abstract}
In recent years, all the conditions of access to the Chinese market by foreign companies have been continuously and greatly improved with greater market openness in industries including transportation, finance and infrastructure. The elimination special requirements for foreign companies and passage of the Comprehensive Agreement on Investment are also positive moves. Despite the impact of COVID-19, it is expected that there will be continued expansion across sectors in the future.
\end{abstract}

Keywords Greater market openness • Transportation • Finance $\cdot$ Infrastructure • Comprehensive agreement on investment $\cdot$ COVID-19

Since China's accession to the World Trade Organization in December 2001, the business environment in China has been increasingly favorable to the collaborations between Chinese and foreign companies as well as to foreign investments. On the other hand, with the clear government impetus to develop national technological sovereignty and its target to have industrial national champions in place within the next five to ten years, the competitive environment has intensified tremendously. The regulatory scrutiny has somewhat dulled some of the effects of the former redcarpet welcome policy for foreign enterprises that prevailed in the past. In this new paradigm, new challenges have appeared. In order to do business efficiently, foreign enterprises will need to demonstrate, on a constant basis, the undeniable proof of their unique value proposition if they expect to remain relevant and continue their sustainable growth in the country.

\section{China-Increased Flexibility and Market Openness}

In recent years, the conditions for foreign companies to access the Chinese market have been continuously and greatly improved. The recent release of another set of

\footnotetext{
C. Lauras $(\bowtie)$

CCI France Chine, Beijing, China
}

(C) The Author(s) 2022

H. Wang and L. Miao (eds.), Transition and Opportunity, China and Globalization, https://doi.org/10.1007/978-981-16-8603-0_7 
regulations on optimizing the business environment was of course greatly appreciated by the foreign community. These regulations aimed at providing equal protection to all market entities, ensuring that they could make equal use of all the factors of production and ensure that they enjoyed support policies in accordance with the law. They also clarified the rules regarding faster registration of enterprises, equal market access, solid implementation of tax and fee reduction policies, and the easing of financing difficulties. The regulations also detailed what we found were welcome efforts, at least on paper, in cutting red tape, streamlining administrative approvals, and improving supervision and the administrative law enforcement.

Interestingly, while we have observed a global trend in strengthening controls over foreign investment in many parts of the world. China decided at the end of June 2020 to make its regulations more flexible and widen the number of sectors eligible for this type of investment. This decision represents a great improvement for many companies and is particularly remarkable for some key sectors:

- In the transportation sector, where the regulations prohibiting foreign investment in air traffic control have been removed and the regulations on entry into civil airports have been adapted.

- In the financial sector, a foreign entity can now hold full capital shares in an insurance company and the restrictions on brokerage houses, rating agencies, wealth management companies and funds have been lowered.

- In the area of infrastructure, where the rule stipulating that water supply systems for cities over 500,000 inhabitants must be controlled by a Chinese entity is no longer mandatory.

We also noted that nuclear fuel processing, agricultural R\&D and higher education were listed among the other eligible sectors for foreign investment.

In addition, on January 1, 2020, the Chinese government announced the termination of the Wholly Foreign-Owned Enterprises and Joint Venture system. After a transition period of five years, this system will be replaced by a single status for both Chinese and foreign companies, a move that demonstrates the strong will of the Chinese authorities to introduce more equitable treatment for companies operating in China.

In terms of multilateral relations, China and Europe are increasing exchanges and the recent signing of the EU-China comprehensive agreement sets an ambitious opening and level playing field for European investments.

In this agreement, as far as the terms of market access for EU businesses are concerned, China has made significant commitments in the field of manufacturing, the most important sector for EU investment in China. Manufacturing makes up more than half of all EU investment-including 28\% for the automotive sector and $22 \%$ for basic materials. This includes the production of electric cars, chemicals, telecom equipment and health equipment, among others.

China is also making commitments that benefit EU investments in various service sectors, such as cloud services, financial services, private healthcare, environmental services, international maritime transport and air transport-related services. 
In the sectors covered, and if the terms of the agreement are confirmed and applied, French and European businesses would benefit from increased certainty and predictability as their operations in China would no longer be subject to limited access or the introduction of new discriminatory practices.

Also pending confirmation, the agreement would help to level the playing field for EU investors by laying down very clear rules on Chinese state-owned enterprises, transparency of subsidies, and prohibiting forced technology transfers and other distortive practices. It also includes guarantees that would make it easier for European companies to obtain authorizations, complete administrative procedures and secure access to China's standard-setting bodies for European companies.

In a very unexpected and positive development, environmental issues were also addressed in the agreement, which should be considered great news. The China Comprehensive Agreement on Investment (CAI) will bind the parties into a valuesbased investment relationship underpinned by sustainable development principles. This is the first time that China has agreed to such ambitious provisions with a trade partner.

China is also undertaking commitments in the areas of labor and environment, promising not to lower the standards of protection in order to attract investment, to respect its international obligations, and to promote responsible business conduct by its companies. China has also agreed to effectively implement the Paris Agreement on climate change as well as to effectively implement the International Labour Organization Conventions, which has ratified. It has also agreed to make continued and sustained efforts to ratify the ILO fundamental conventions on forced labor.

These sustainable development issues will be subject to a solid enforcement mechanism by an independent panel of experts as in other trade agreements, which means a transparent resolution of disagreements with the involvement of civil society. This actually represents great news for French companies specializing in recycling, clean energy and eco-cities, as they often are leaders in their respective fields and have a lot to offer China's path to sustainability and compliance. Such an agreement was long expected and hopefully will be the first of many milestones in an ever-stronger cooperation partnership.

However, while we have observed that for established French enterprises in China, market access has become increasingly favorable, further improvement in the area of market openness and transparency is still required. While it is of course totally understandable that state-owned enterprises receive special attention, the French Chamber simply emphasizes that it is also important that the rules of equal bidding for opportunities prevail, a matter that we know will continue to evolve and progress positively in the months to come. 


\section{A Comprehensive Strategy Moving Forward}

In such a framework, what strategy should foreign enterprises adopt to adapt this new competitive environment and remain relevant in the fast-paced economic and technological growth of the next five years?

First, they will have to ensure that their value proposition remains undisputable and competitive. Be it the unique technological advantage of a product or the power of brand equity, the demonstration of these added values and unique selling points must remain strong and current. This means that the investments of most enterprises must be channeled toward research and development, initiatives fostering creativity as well as the recruitment of the best talent so that the end product presents an undeniable interest to China's new needs for its development.

Secondly, smart collaboration will be key to any business's long-term growth strategy. A viable and enlightened move in many sectors would be to ensure that its value proposition is intertwined in the canvas of the Chinese economy by ensuring that its product or its service becomes an essential moving part of the entire process of development. This implies finding the most compatible business partner, a move that could also help resolve the many issues linked to a regulatory environment that becomes harder to comply with by the day.

The first question that a corporation should always ask itself is: What sectors matter the most to industrial reformers and am I from one of those? Healthcare, food and chemicals are all famous for the amount of scrutiny and enforcement Chinese regulators load on them. However, this list keeps expanding.

To find the right partner, it may help to have a designated team, including onthe-ground professional advisers and agents, to seek out appropriate targets. The team's primary functions would include conducting a market analysis of players, meeting stakeholders and officials, and building the relationships necessary to begin discussions for any deal. Knowledge of Chinese business culture and etiquette is thus key to making the most of these opportunities.

When seeking partners in China, businesses need to think ahead to issues that may occur post-deal finalization such as local talent recruitment, management and retention, and building flexibility and adaptability into their business models. They should seek out partners that have enough experience in the local industry and familiarity with differences among local consumers and industry segments to see how to carry through with ideas. Above all, these partners should possess the resources and relationships that complement the company's. However, alliances come with their risks. The importance of trust and regular communication cannot be over-emphasized.

\section{The Impact of COVID-19}

One cannot write about optimizing the current business environment in China without mentioning the health crisis that started in winter of 2020. The COVID-19 crisis is 
a historical challenge to countries and economies across the globe. It has of course greatly affected foreign companies present in China, especially in the areas of human resources and organizational practices.

A good business environment should always start with the guarantee of an absolute sense of safety for any entrepreneur, and to that effect, the French Chamber of Commerce in China found the management of the pandemic in China absolutely remarkable. The strength of the health control procedures, their application with resilience and humanity, and the long list of government support and relief measures that were released during the crisis were highly appreciated by the French business community and contributed to a fast and visible economic recovery in the country. This can only give a sense of trust to any entrepreneur and is a very encouraging signal sent toward investors everywhere. This health crisis will, of course, generate cyclical tensions in many sectors this year, but the effects of this will eventually dissipate.

\section{Continued Development and Growth Across Sectors}

We have observed that a large number of industries and sectors are experiencing, and will continue to experience, a significant development in China over the next few years, as the technological and digital transformation of the country continues to accelerate. We are thinking, for example, about the sectors of sustainable cities technologies, clean energies, intelligent urban transport and services, financial services, medical technologies, elder services, and many more. French companies, which are very advanced in these fields, are already strong partners in China and will definitely continue to take part in the growing needs of the development of the Chinese economy and society.

There are still many opportunities open to French and European companies, thanks to the pledge by Chinese authorities to create a business environment that is more favorable to foreign players, even if some questions remain on their modes of application.

While enough has been said about the COVID-19 crisis, and while the words "unprecedented" and "new normal" have been more than overused, it is still a huge large understatement to say that 2021 has been a crucial year for China and for the global economy in general.

\section{Pride in Our Achievements and Looking Forward}

Looking back, we can first be very proud of what was achieved under such dramatic circumstances. During these very testing times, our entrepreneurs in China have clearly shown their resilience, their creativity and their agility. We have seen that French companies in China have quickly evolved to adjust to the ever-changing 
market landscape and we are convinced that they will, without a doubt, continue to adapt to new economic paradigms while embracing China's transformation. In these matters, the French Chamber of Commerce and Industry in China has been, and remains, fully mobilized to provide the business community with the best platform of services that accompany the needs of French companies and facilitate their sustained development.

In fact, the arrival of the pandemic in 2020 emphasized the fact that foreign enterprises, more than ever, need the support of institutional platforms such as their relevant Chambers of Commerce. The role of the CCI France Chine during the pandemic was crucial to keeping all lines of communication open, helping companies and individuals resolve specific issues and serving as a much-needed hub of resources and solidarity during a difficult crisis.

The role of the Chamber was also key in driving the results during the recovery period as we conducted multiple sectoral activities very early on to help companies prepare future strategies and make the most of the economic reset following the lockdown.

The word "recovery" has been overused in 2021, but we are all grateful. This coming year will be, hopefully, a period where enterprises, countries and societies can heal and recover in the best possible manner.

The global economic recovery begins in China; we are already witnessing it. In a market that is more open to foreign investment, multinationals and SMEs present on this market will benefit from the rebound effect. Although a lot remains to be clarified and improved to facilitate the development of foreign enterprises in China, we are convinced that after this crisis is over, France and China will continue their strong partnership and take advantage of the new and very promising prospects opening up for the development of economic prosperity centered on multilateral equity.

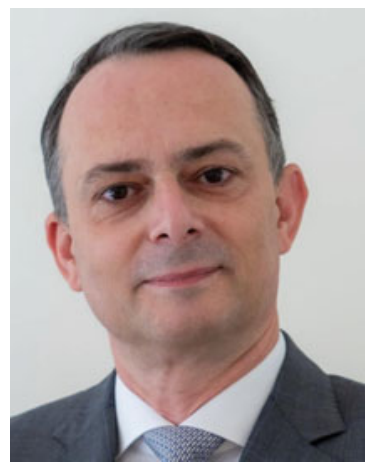

Christophe Lauras is the President of the French Chamber of Commerce and Industry in China (CCI France Chine). Hotelier by profession, he is Senior Vice President Operations for the Accor Group in Greater China. Born in France in 1967, Christophe Lauras studied hospitality management in Dijon and then started his career in Great Britain. He joined the Accor hotel group in 1989 and worked successively in New Caledonia, Indonesia, India and China where he managed and opened several flagship hotels from the Accor brand's portfolio before joining Accor's Shanghai head office. In China since 2000, Christophe Lauras has served the French Chamber for more than 15 years. 
Open Access This chapter is licensed under the terms of the Creative Commons AttributionNonCommercial-NoDerivatives 4.0 International License (http://creativecommons.org/licenses/bync-nd/4.0/), which permits any noncommercial use, sharing, distribution and reproduction in any medium or format, as long as you give appropriate credit to the original author(s) and the source, provide a link to the Creative Commons license and indicate if you modified the licensed material. You do not have permission under this license to share adapted material derived from this chapter or parts of it.

The images or other third party material in this chapter are included in the chapter's Creative Commons license, unless indicated otherwise in a credit line to the material. If material is not included in the chapter's Creative Commons license and your intended use is not permitted by statutory regulation or exceeds the permitted use, you will need to obtain permission directly from the copyright holder.

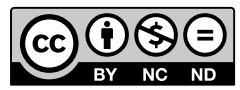

